\title{
From Gaullism to Anti-Gaullism: Denis Saurat and the French Cultural Institute in Wartime London
}

DOI:

10.1177/0022009417699866

\section{Document Version}

Accepted author manuscript

Link to publication record in Manchester Research Explorer

\section{Citation for published version (APA):}

Faucher, C. (2019). From Gaullism to Anti-Gaullism: Denis Saurat and the French Cultural Institute in Wartime London. Journal of Contemporary History, 54(1), 60-81. https://doi.org/10.1177/0022009417699866

\section{Published in:}

Journal of Contemporary History

\section{Citing this paper}

Please note that where the full-text provided on Manchester Research Explorer is the Author Accepted Manuscript or Proof version this may differ from the final Published version. If citing, it is advised that you check and use the publisher's definitive version.

\section{General rights}

Copyright and moral rights for the publications made accessible in the Research Explorer are retained by the authors and/or other copyright owners and it is a condition of accessing publications that users recognise and abide by the legal requirements associated with these rights.

\section{Takedown policy}

If you believe that this document breaches copyright please refer to the University of Manchester's Takedown Procedures [http://man.ac.uk/04Y6Bo] or contact uml.scholarlycommunications@manchester.ac.uk providing relevant details, so we can investigate your claim.

\section{OPEN ACCESS}


Journal of

Contemporary History

\section{From Gaullism to anti-Gaullism: Denis Saurat and the French cultural institute in wartime London.}

\begin{tabular}{|c|c|}
\hline Journal: & Journal of Contemporary History \\
\hline Manuscript ID & JCH-Sep-2016-1127.R1 \\
\hline Manuscript Type: & Article \\
\hline Keywords: & $\begin{array}{l}\text { Anti-Gaullism, External resistance, France, Institut Français du Royaume } \\
\text { Uni, London, Second World War }\end{array}$ \\
\hline Abstract: & $\begin{array}{l}\text { This article explores the case of the French cultural institute in London } \\
\text { which found itself at the nexus of Gaullist as well as anti-Gaullist networks } \\
\text { during the Second World War. By analysing the support that the institute's } \\
\text { director, Denis Saurat, brought to Charles de Gaulle in the early days of } \\
\text { Free France, the article contributes to our understanding of the formation } \\
\text { of Free French political thought. This study analyses Saurat's shifting } \\
\text { position in the movement, from being Gaullist to becoming an active } \\
\text { partisan of anti-Gaullism. The examination of Saurat's networks and } \\
\text { politics helps to re-appraise further trends of anti-Gaullism caused by leftist } \\
\text { views not least regarding the lack of democratic principles that } \\
\text { characterised Free France in } 1940-1942 \text {. Finally, Saurat's anti-Gaullism } \\
\text { was also prompted by his refusal to put the French cultural institute in } \\
\text { London at the service of de Gaulle and support Free French propagandist, } \\
\text { cultural and academic ambitions in the world. Overall this article argues for } \\
\text { a reassessment of London-based leftist anti-Gaullism understood not just } \\
\text { through issues of personalities and democracy but also through the prism } \\
\text { of cultural diplomacy and propaganda. }\end{array}$ \\
\hline
\end{tabular}

\section{SCHOLARONE" \\ Manuscripts}


From Gaullism to anti-Gaullism: Denis Saurat and the French cultural institute in wartime London.

\begin{abstract}
This article explores the case of the French cultural institute in London which found itself at the nexus of Gaullist as well as anti-Gaullist networks during the Second World War. By analysing the support that the institute's director, Denis Saurat, brought to Charles de Gaulle in the early days of Free France, the article contributes to our understanding of the formation of Free French political thought. This study analyses Saurat's shifting position in the movement, from being Gaullist to becoming an active partisan of anti-Gaullism. The examination of Saurat's networks and politics helps to reappraise further trends of anti-Gaullism caused by leftist views not least regarding the lack of democratic principles that characterised Free France in 1940-1942. Finally, Saurat's anti-Gaullism was also prompted by his refusal to put the French cultural institute in London at the service of de Gaulle and support Free French propagandist, cultural and academic ambitions in the world. Overall this article argues for a reassessment of London-based leftist anti-Gaullism understood not just through issues of personalities and democracy but also through the prism of cultural diplomacy and propaganda.
\end{abstract}

Keywords: Anti-Gaullism, External resistance, France, Institut Français du Royaume Uni, London, Second World War

Corresponding Author Contact details

Dr. Charlotte Faucher

Department of History,

University of Warwick,

Humanities Building,

Coventry, CV4 7AL

c.faucher.1@warwick.ac.uk

07905659563

Ack 
I should like to thank the anonymous reviewers as well as Craig Griffiths, Julian Jackson and Colin Jones for their helpful comments and suggestions. A shorter version of this article was presented at the Modern French History seminar (Institute of Historical Research, London) and I am grateful to the audience present on that occasion for their stimulating feedback.

Bio

Charlotte Faucher is Teaching Fellow in Modern History at the University of Warwick. She is currently co-editing with Laure Humbert a special issue on the French external resistance and its international networks to be published in the European Review of History: Revue européenne d'histoire. Her book on French cultural diplomacy in twentieth-century Britain is in progress. 
For a brief moment in 1940, the French cultural institute in London, the Institut Français du Royaume-Uni (IFRU), was at the centre of the world historical stage. This was initially owing to the support it brought to Charles de Gaulle's nascent Free French movement; but only a few years later, the institution would find itself at the nexus of French and British anti-Gaullist movements. Charles de Gaulle was a relatively unknown forty-nine-year-old General when he pronounced his 18 June Appeal, which laid the foundation for the Free French movement. Few people actually heard his speech broadcast on the BBC, and de Gaulle's first days in London were plagued by doubts and disappointments as important military and political figures refused to join him. However, he found strong support from Denis Saurat, the director of the IFRU, which by June 1940 was a well-established institution for the British Francophile elite and the French community in London. The IFRU had been created in 1910 by a 24-year-old French woman, Marie Orliac. It was (and remained until 1945) a British association which initially offered lectures, language classes, and social gatherings to wealthy young women and ladies. This imitation of a finishing school became an academic establishment modelled on other Institut Francais in Europe when, in 1913, Orliac established a partnership with the University of Lille. ${ }^{1}$ In 1922, the University of Paris joined in and together with Lille oversaw the pedagogical and academic affairs of the IFRU. Both universities encouraged their students to attend courses at the institute which had been granted degree awarding power since 1913. ${ }^{2}$ Denis Saurat's

\footnotetext{
${ }^{1}$ The first Institut français opened in Florence opened in 1907 and was partnered with the University of Grenoble. The Institut Français in Madrid was the result of the collaboration between Ernest Mérimée from the University of Toulouse and Pierre Paris from Bordeaux; it opened in July 1909. Two years later, an Institut Français opened in St Petersburg with the support of the University of Paris. For the early histories of these institutions, see Isabelle Renard, L'institut français de Florence 1900-1920 : un épisode des relations franco-italiennes au début du XXe siècle (Rome, 2001); Jean-Marc Delaunay, Des Palais En Espagne: l'École Des Hautes Études Hispaniques et La Casa de Velázquez Au Cour Des Relations Franco-Espagnoles Du XXe Siècle (1898-1979) (Madrid 1994). Vladislavi Rjéoutski and Christian Faure, "L'Institut Français de Saint-Petersbourg," in L'alliance Française et l'institut Francais de SaintPetersbourg, Essais Historiques (St Petersbourg 2001); Olga Medvedkova, "'Scientifique' Ou 'Intellectuel'? Louis Réau et La Création de 1'Institut Français de Saint-Pétersbourg," Cahiers Du Monde Russe 43, no. 2/3 (April 1, 2002): 411-21.

2 Chantal Morel, "L’entente cordiale (1910-1938)," in Virginie Dupray, René Lacombe, and Olivier Poivre d'Arvor (eds.) Londres sur Seine : Une histoire de l'Institut français du Royaume-Uni (19101980), (Paris 1996); Anne-Elisabeth Buxtorf, "100 Years on: A Brief History of the Institut Français in London” (translated by Camille Regnault)," French Studies Library Group Annual Review, no. 6 (20092010): 10-12
} 
${ }^{3}$ Centre des Archives Diplomatiques de Nantes (thereafter CADN), 378 PO C2 253. Résumé du dossier du Consul, May 1944 ; The National Archives (thereafter TNA), BW 31/23. Ellul to Lane with an enclosed letter from Ellul to Bessborough, 9 December, 1944.

${ }^{4}$ CADN, 378 PO C2 253. Programme of events at the IFRU (1940-1945).

${ }^{5}$ Credit must nonetheless be given to Jean-François Muracciole's short but accurate bibliographical note in the Dictionnaire de La France Libre in which he sums up Saurat's engagement and opinions during the Second World War. Muracciole, "Saurat, Denis (1890-1958)," François Broche, Jean-François Muracciole, and Georges Caïtucoli (eds.) Dictionnaire de La France Libre (Paris 2010). There are also two non-academic biographies on Saurat John Robert Colombo, O Rare Denis Saurat: An Appreciation (Toronto 2003) and John Robert Colombo, The Denis Saurat Reader (Shelburne, 2004).

${ }^{6}$ Charles de Gaulle, speech delivered in Algiers for the 60th anniversary of the Alliance Française, 30 October 1943, http://www.fondation-alliancefr.org/?cat=538, accessed 6 June 2014. 
in a positive light, only mentioning Saurat's early rallying. ${ }^{7}$ The absence of Saurat in many studies of Free France can be ascribed to the fact that although Saurat was a leftwing radical intellectual, he never belonged to any resistance political groups during the war (such as the socialist Jean Jaurès group) which perhaps could have gained him some recognition; nor did he ever occupy any official positions with Free France. As this article will demonstrate, Saurat's war-time political views were flexible to say the least, shifting from a support of de Gaulle's conservative tendencies through to a leftwing, democratic and international stance which jarred with de Gaulle's views. Thus Saurat's political disagreement with Free France and de Gaulle's subsequent ambition to suspend him from his duties in London might also explain his absence from histories of the French Resistance. This is indicative of a larger flaw in the historiography of Free France, which tends to be built around the supporters of the movement and often fails to acknowledge dissidence and challenges. This article offers a corrective to this approach.

Through an analysis of the Saurat-de Gaulle relationship and drawing on the neglected personal papers of Denis Saurat, on Free French archives available in Britain and France and on Foreign Office documents, this article contributes to the historiography of Free France not just in terms of the biographies of the two men, but also for the whole French resistance movement in Britain - and London in particular. ${ }^{8}$ Notably the article reconsiders the political genesis of Free France as well as the disappointments and criticisms it engendered amongst some of its early London-based supporters. Memoirs and scholarly analyses have discussed at great length the constitution of the political France Libre and its military wing, the Free French Forces. ${ }^{9}$ However, little is known

\footnotetext{
${ }^{7}$ Charles de Gaulle, Mémoires de Guerre: v.1. L'appel - 1940-1942 (Paris 1954), 68.

${ }^{8}$ Other works have recently focused on international, London-based resisters such as Philippe Oulmont's biography of Pierre Denis who, much like Saurat, was a cosmopolitan anglophile. While Denis did not break with de Gaulle, he vacillated between his loyalty to and admiration of de Gaulle and his pre-war ties with Monnet. His wartime trajectory highlights competing strategies among Free France in London and Algiers. See Philippe Oulmont, Pierre Denis, Free Frenchman and Citizen of the World (Paris: Nouveau Monde, 2013).

${ }^{9}$ On the political and diplomatic history of Free France see Jean Louis Crémieux-Brilhac, La France Libre. De l'Appel du 18 juin à la Libération (Paris 1996); Henri Michel, Histoire de La France Libre (Paris 1963); Pierre de Broissia, La France Libre : l'épopée des Français libres au combat, 1940-1945, (Paris 2004); François Broche, Jean-François Muracciole, and Georges Caïtucoli (eds.), Dictionnaire de La France Libre (Paris 2010). Regarding the French National Committee and later the French Committee of National Liberation, see Yves-Maxime Danan La Vie Politique à Alger de 1940 à 1944 (Paris 1963);
} 
André Kaspi La mission de Jean Monnet à Alger (Paris 1971); Jean Baptiste Duroselle L'abime. 19391945 (Paris 1983).

${ }^{10}$ The fact that the literature has overlooked the early history of Free French political thought has been noted by historians; see for example Julian Jackson, "L'homme du 18 juin : vérité et légende," in $D e$ Gaulle chef de guerre : De l'appel de Londres à la libération de Paris, 1940-1944, ed. Philippe Oulmont, (Paris 2008), 31.

${ }^{11}$ For a discussion on Vichy supporters among the French community established in Britain, see Nicholas Atkin, The Forgotten French: Exiles in the British Isles, 1940-44 (Manchester 2003).

12 The largest study on anti-Gaullism during the Second World War to date mostly focuses on tensions between de Gaulle, Vichy, the internal resistance and giraudism. Only a few chapters address antiGaullism among the external resistance. Robert Belot, La résistance sans de Gaulle : politique et gaullisme de guerre (Paris 2006); François Broche, Une histoire des antigaullismes : des origines à nos jours (Paris 2007); Jean-Louis Crémieux-Brilhac, La France Libre; Atkin, The Forgotten French; Julian Jackson, "General de Gaulle and His Enemies: Anti-Gaullism in France since 1940," Transactions of The Royal Historical Society sixth series, no. xi (1999): 43-65. On anti-Gaullism within the right-wing French Resistance see Valerie Deacon, "Fitting in to the French Resistance: Marie-Madeleine Fourcade and Georges Loustaunau-Lacau at the Intersection of Politics and Gender," Journal of Contemporary History 50, no. 2 (April 1, 2015): 259-73.

${ }^{13}$ Pierre Bloch, De Gaulle, ou Le temps des méprises (Paris 1969), 49; Colonel Passy, Souvenirs, vol 2 (Monte-Carlo 1947), 220-226.

${ }^{14}$ Pierre Bloch, De Gaulle, ou Le temps des méprises, 99.

${ }^{15}$ The only study on the Jean Jaures group is a MA dissertation, Emmanuelle Rey, "La dissidence socialiste à Londres: le groupe Jean Jaurès et le quotidien France (août 1940-août 1944)" (MA thesis, Paris I, 1998); Other historians allude to the group: Jean-Louis Crémieux-Brilhac, Georges Boris : trente ans d'influence: Blum, de Gaulle, Mendès France (Paris 2010), 147-149; Daniel Cordier, Jean Moulin: la République des catacombes (Paris 1999), 83-86. 
This article opens with a study of the relationship between the French institute and the Free French, between Saurat and Charles de Gaulle, from the summer of 1940 until late 1942. At the time many commentators, including the socialist lawyer André WeilCuriel, saw the institute as 'the first bastion of the Resistance. ${ }^{16}$ This situation was however short-lived, and the article will assess how and why Saurat turned 'one of the centres of French life' in London, to borrow from de Gaulle's description of the institute, ${ }^{17}$ into an establishment hostile towards the Gaullist movement. The rest of this essay expands on Saurat and de Gaulle's tumultuous relationship in order to analyse how Saurat and his entourage gradually formed an anti-Gaullist movement. Historians have tended to stress that anti-Gaullism was based on personal rivalries and ambitions. Although this point is valid for the Saurat-de Gaulle relationship, at issue here are ideological and political disagreements between Saurat and de Gaulle for both figures had diverging views on the role of democracy and internationalism within Free France. . However, as the article demonstrates, Saurat's anti-Gaullism did not only pertain to these two issues, but was also driven by a reaction against de Gaulle's ambition to use the French cultural institute in London as the basis for Free French cultural policies and 'academic diplomacy'. ${ }^{18}$ Although historians of the French metropolitan resistance have analysed in depth the concept and issues around the 'intellectual resistance', ${ }^{19}$ much remains to be said about the intellectual activities of the external Resistance. By looking at Saurat as an agent of 'intellectual resistance' and building on the growing interest in intellectual emigration during the Second World $\mathrm{War},{ }^{20}$ this article illuminates questions

\footnotetext{
${ }^{16}$ André Weil-Curiel, Le Temps de La Honte Vol. 3. Voyage En Enfer, 1940 (Paris 1947), 203. Debra Kelly and Martyn Cornick, eds., "'The First Bastion of the Resistance': The Beginnings of the Free French in London, 1940-1," in A History of the French in London: Liberty, Equality, Opportunity (London 2013).

${ }^{17}$ De Gaulle, Mémoires de Guerre, 240.

${ }^{18}$ Guillaume Tronchet, "Diplomatie Universitaire Ou Diplomatie Culturelle ? La Cité Internationale Universitaire de Paris Entre Deux Rives (1920-1940)," in La Babel étudiante. La Cité Internationale Universitaire de Paris (1920-1950), ed. Guillaume Tronchet and Dzovinar Kévonian (Rennes 2013), 5988.

${ }^{19}$ Gisele Sapiro, The French Writers' War, 19540-1953 (Durham and London, 2014); Anne Simonin, Les Éditions de Minuit, 1942-1945. Le devoir d'insoumission (Paris, 1994); Jacques Debu-Bridel, La Résistance intellectuelle (Paris 1970).

${ }^{20}$ In the case of French intellectuals abroad see Emmanuelle Loyer, Paris à New York: intellectuels et artistes français en exil (1940-1947) (Paris 2005); Christopher E. G. Benfey and Karen Remmler, eds., Artists, Intellectuals, and World War II: The Pontigny Encounters at Mount Holyoke College, 1942-1944
} 
about the role and influence of arts within Free France. It also highlights the power struggles that took place outside France in the field of French cultural politics when, in the case of London, Charles de Gaulle sought to gain the upper hand over the French cultural realm as it had developed since before the First World War.'

Denis Saurat was born in Toulouse in 1890 . His education and career were characteristic of the social rise of the French middle class, the couches moyennes, through school and university. Born in a rather modest family, he entered an école normale in the North of France at 15 . His talent led him to embark upon university studies at the University of Lille, where he read English and learned Latin. Against the will of his parents, he married Ella Smidt, the daughter of a London-based German family. After working as a secondary school teacher in France for a few years, he became a French language assistant at the University of Glasgow in 1917-1919, before he took the competitive English agrégation exam in 1919, in which he ranked first. In Scotland, he developed an interest in occultism and esotericism and grew closer to the communist and Scottish nationalist poet Christopher Murray Grieve, better known by his pen name Hugh MacDiarmid, who considered Saurat his 'oldest and best friend' ${ }^{21}$ This link with one of the most enduring communists in British post-war life highlights Saurat's political inclinations. His French network reveals similar sympathies for he was also particularly close to the communist writer Jean-Richard Bloch, whose political opinions, as he would later admit, he did not share.22 The letters the two men exchanged in the inter-war period reveal that Saurat was a pacifist; they further suggest that Saurat slowly shifted from supporting the Radical Party in the 1920s towards socialism and popular front

(Amherst 2006). Regarding the intellectual contribution to post-war Europe of European politicians in exile in Britain and the USA, see W. Kaiser, "Co-Operation of European Catholic Politicians in Exile in Britain and the USA during the Second World War," Journal of Contemporary History 35, no. 3 (July 1, 2000): 439-65

${ }^{21}$ Letter to Andrew Graham Grieve, 18 December, 1939: quoted in Dorian Grieve, Owen Dudley Edwards, and Alan Riach, eds., Hugh MacDiarmid: New Selected Letters (Manchester 2001), 172-173. Michel Byrne, “Tails O the Comet? MacLean, Hay, Young and MacDiarmid's Renaissance," ScotLit, 26 (Spring 2002). 22 Denis Saurat, Europe, 39 (1957), 135-136. Conversation with Saurat's son Harold in Colombo, The Denis Saurat Reader, 20. 
politics in the 1930s (Saurat for example endeavoured to receive at the IFRU the socialist weekly Vendredi). However by 1939, Saurat would confess to Bloch that he had relinquished grasping contemporary political and preferred devoting his time to metaphysics and literature. This attitude perhaps explains why it is somewhat difficult to situate him distinctly on the political spectrum. ${ }^{23}$ Notwithstanding his politics, he was a baptised and confirmed Catholic, like the majority of interwar French society, and adhered to the ideal of a Catholic France. ${ }^{24}$ Like many other French intellectuals who observed with concern the economic and social changes which had occurred since the early 1930s, Saurat elaborated in 1939 on the idea of a 'crisis of civilisation'. The answer, he thought, lay in a 'necessary Christian society'. ${ }^{25}$

Saurat was appointed director of the IFRU in 1924, a role that he combined from 1926 with the position of Chair of French language and literature at King's College, London. As head of the French cultural institute in London Saurat developed friendships and working relations with many British intellectuals including Alfred Orage, the British editor of the political and literary review New Age. As an active agent of cultural internationalism Saurat attended many European intellectual gatherings such as the Décades de Pontigny or the PEN Club which he joined in 1935.26 He would grow close to Hermon Ould and Margaret Storm Jameson, two prominent writers and personalities

\footnotetext{
${ }^{23}$ Bibliothèque nationale de France, Mss, Fonds Jean-Richard Bloch, Naf 28222, Correspondance, Lettres reçues, Vol XLII, I am grateful to Rachel Mazuy for drawing my attention to these letters.

${ }^{24}$ Testimony of Denis Saurat's children, in Colombo, O Rare Denis Saurat, 28 and 84. Saurat published extensively on Milton, Blake and Hugo on non-Christian elements of occultism and cabalism, see Denis Saurat, La Religion de Victor Hugo (Paris: Hachette, 1929); Denis Saurat, The Three Conventions. Metaphysical Dialogues, Principia Metaphysica, and Commentary (New York: Lincoln MacVeagh, 1926); Jeffrey Shoulson, "Man and Thinker: Denis Saurat, and the Old New Milton Criticism," in The New Milton Criticism, by Peter C. Herman and Elizabeth Sauer (Cambridge University Press, 2012), 194-211. On religious practices in France during the interwar period, see Eugen Weber, The Hollow Years: France in the 1930s (New York; London: Norton, 1994), 186.

${ }^{25}$ On the notion of 'crisis of civilisation', see Serge Berstein, La France des années 30 (Paris 1993), 80; Denis Saurat, The Spirit of France (London 1940), 53.

${ }^{26}$ On cultural internationalism, see Akira Iriye, Cultural Internationalism and World Order (Baltimore, Md; London 1997); Jessica Reinisch, "Introduction: Agents of Internationalism," Contemporary European History 25, no. 2 (May 2016): 195-205; François Chaubet, Paul Desjardins et les Décades de Pontigny (Villeneuve-d'Ascq France 2000); François Chaubet, "Les Décades de Pontigny (1910-1939)," Vingtième Siècle, no. 57 (March 1998): 36-44; François Chaubet, Histoire intellectuelle de l'entre-deuxguerres : culture et politique (Paris 2006), 126-129.
} 
of the Club. ${ }^{27}$ Saurat's interests and networks partly shaped the IFRU as a space which welcomed Franco-British as well as international intellectual cooperation, a feature which would become even more apparent during the Second World War. Concomitantly, he strengthened connections with French artists and intellectuals who would come and lecture at the IFRU such as Jules Romains, the French writer who was at the head of the PEN club and who he would succeed in 1941 (Saurat retained this post until 1947).

Pascal Ory and Jean-François Sirinelli have described the Second World War as the second most important event in French intellectual history after the Dreyfus Affair. In reaction to the rise of fascism and totalitarianism but mostly boosted by the presence of de Gaulle in London, Saurat came to fit Ory and Sirinelli's definition of an intellectual: 'a person of culture, creator or mediator, placed in the situation of a politician, producer or consumer of ideology'. ${ }^{28}$ Denis Saurat brought an immediate support and devotion to de Gaulle in June 1940. His attitude was rooted in his emotional and intellectual response towards the war and the Armistice. The two men shared an admiration of France, which they would both come to express through the words of Péguy, and believed that France had to stay in the war and fight against Germany. ${ }^{29}$ Saurat did not hear de Gaulle's 18 June Appeal, but having discovered his address in The Times, he went the following day to de Gaulle's small flat in Seamore Place with some of his close friends: the Francophile Lord Ivor Spencer Churchill, the prime minister's cousin, and Jacques Métadier, a member of the French Intelligence Mission in London. ${ }^{30}$ Also present were Henri Hauck, who was the representative of the French trade union Confédération Générale du Travail (CGT), as well as Geoffroy de Courcel, aide-de-

\footnotetext{
${ }^{27}$ TNA, BW 31/23, Ellul to Hermon Ould, 6 November 1944.

${ }^{28}$ Pascal Ory and Jean-François Sirinelli, Les intellectuels en France de l'affaire Dreyfus à nos jours (Paris 1992), 10.

${ }^{29}$ Archives de I'Institut Français du Royaume-Uni (thereafter AIFRU), Denis Saurat Archives (thereafter DSA) 21. 20 June 1940: [Entretien Saurat/Morvan/Masson]; Julian Jackson, "De Gaulle before Oxford" (De Gaulle Before Oxford, 25 November 1941, Maison française d’Oxford, 2011), http://www.mfo.ac.uk/?q=en/podcasts/de-gaulle-oxford-25-november-1941; Henk Wesseling, Certain Ideas of France: Essays on French History and Civilization (Westport, Conn. and London 2002), chapter 10. Charles de Gaulle and Charles Peguy: A Certain Idea of France.

${ }^{30}$ Archives Nationales (thereafter AN), 72 AJ 220. Denis Saurat - interview by Mme Granet, September 1951. The meeting is also mentioned in Crémieux-Brilhac, La France Libre, 96.
} 
camp to de Gaulle. On that day, Saurat had had two meetings with Métadier during which both men agreed to 'carry on the fight, and disowned the government'. ${ }^{31}$

In the early hours of 19 June 1940, before he had even met with de Gaulle, Saurat had taken part with Métadier in the drafting of the 'Proclamation of the French people', which Lord Ivor Churchill handed to 10 Downing Street on the same day. This group of 'still free' French men living in Britain claimed that a government consisting of 'Free and worthy French men' had been set up in London. In a speech rhetorically close to de Gaulle's June 18 Appeal, they proceeded to invite officers from their navy, air force and colonial services to join them in the fight against Germany. The name of de Gaulle and the singular pronoun 'I' are conspicuously missing from the draft, but Foreign Office official William Strang, and historians after him such as Jean-Louis Crémieux-Brilhac, believed the document to have been drafted by de Gaulle alone. In fact, the Denis Saurat papers reveal that de Gaulle was not present during the drafting of the speech. ${ }^{32}$ Strang was both ill at ease as to its content and reluctant to show any form of support to these self-claimed 'Free men' at a moment when Britain was still, as he put it, 'gingering up the present [French] government, and with some success. ${ }^{33}$ Although it is difficult to assess the influence of de Gaulle on the genesis of this document, its exclusion from many early histories of Free France has concealed the fact that French resisters in London, and not just de Gaulle, had sought to form a government or a legitimate committee in London even before the government had signed the Armistice with Germany on 22 June 1940. This is also indicative of how the history of Free France has been written, with an emphasis on successful undertakings rather than failed attempts, on fruitful collaborations rather than parallel projects. ${ }^{34}$

The news of the signing of the Armistice rapidly spread in Britain. On June 23, de Gaulle expanded on the political shape that his movement should take. He met with

\footnotetext{
${ }^{31}$ AIFRU, DSA 35, June 19.

${ }^{32}$ AIFRU, DSA 35, 'Proclamation of the French people', 19 June 1940.

${ }^{33}$ TNA, FO 371/24349 C 7389/G 2. Note by W. Strang, 19 June 1940.

${ }^{34}$ Valerie Deacon makes a comparable point regarding the historiography of the internal French Resistance when she notes the frequent exclusion of extreme-right wing resistance fighters and women who traditionally have not fitted comfortably in existing narratives. See Valerie Deacon, 'Fitting in to the French Resistance'
} 
Saurat, the writer André Maurois, the ambassador Charles Corbin, the députés Henri de Kérillis and Pierre-Olivier Lapie, and Henri Hauck; together they elaborated on the idea of a Free French Committee. Although this committee was recognised officially by the British government, ${ }^{35}$ it was ultimately still-born, as Lapie, de Kérillis and Corbin withheld their support, thus leading to it being abandoned (a functioning French national committee would be created on 24 September 24 1941). ${ }^{36}$ From 19 June until 10 July, Saurat typically met de Gaulle at least daily. At this point, he was the only intellectual in de Gaulle's immediate circle and expressed his admiration for de Gaulle, telling his close friends Hermon Ould and Margaret Storm Jameson: 'Keep your eyes on him, he isn't only one man, he is France, my France. I'll do anything on earth for him'. He continued: "it rather looks as though no writer had had the sense to follow him to London', thus further noting the absence of Alain, Jean Giraudoux, André Gide, François Mauriac and Jules Romains. ${ }^{37}$ According to Saurat's report, de Gaulle shared the same sense of disappointment:

Ten times a day [de Gaulle] would repeat: "If any one of influence would come forward! In Morocco or in Algiers. I shall ask the English for a plane. I shall go to Noguès, report for orders, ask for a regiment, and fight again. Any one - any one!" But there was no one. ${ }^{38}$

In addition to the fact that de Gaulle was seen as a conservative outsider by many intellectuals, he experienced relative isolation in the early days of Free France owing to the negative connotations of disloyalty to the nation and the political inefficacy attached to exile in French political culture. ${ }^{39}$ Regardless of this, the Gaullist myth was developing in London. Julian Jackson has identified October 1940 as a key date; he

${ }^{35}$ TNA, FO 371/ 24349 C 7389/G 5. French National Committee: messages addressed to General de Gaulle. Crémieux-Brilhac, La France Libre, 69-70.

${ }^{36}$ Despite the failure of the initial project, de Gaulle announced on 26 June 1940 his intention to constitute a 'légion Française volontaire'. This was acknowledged two days later by the British government, which accepted him as the 'the leader of all free Frenchmen, wherever they may be, who rally to him in support of the Allied cause'.

${ }^{37}$ Storm Jameson, Journey from the North, Volume 2: Autobiography of Storm Jameson (London 2011).

${ }^{38}$ Denis Saurat, Watch over Africa (London 1941), 5.

${ }^{39}$ On the notion of exile during the Second World War, see Loyer, Paris à New York; Belot, La résistance sans de Gaulle, 88-120; On the abscence of intellectuals and political figures around de Gaulle, see Robert Tombs and Isabelle Tombs, That Sweet Enemy: The French and the British from the Sun King to the Present (London: William Heinemann, 2006), 573-574. 
suggests that it was at this time that de Gaulle realised the public had come to perceive him as a political figurehead around which they could project their ideals. ${ }^{40}$ Already in September 1940, Saurat participated in the promotion of de Gaulle's image, attributing to himself the clear aim of 'building [de Gaulle] into a myth' and 'pursuing and strengthening the legend of de Gaulle', ${ }^{41}$ thus corroborating Sudhir Hazareesingh's theory that 'the Gaullian myth did not belong only to its creator'. ${ }^{42}$

There was, on the part of Saurat, a real devotion to de Gaulle. For de Gaulle, on the other hand, Saurat was primarily a way of gaining access to the French population in London. ${ }^{43}$ He could offer much to de Gaulle: he knew London, its people - including wealthy and powerful Francophiles - the media and some of the most famous Frenchmen in the capital. ${ }^{44}$ On 20 June 1940 Saurat had been the second guest, after Charles Corbin, invited to speak on 'Ici la France', which had made its debut on the BBC the day before. ${ }^{45}$ Interviewed by Yves Morvan (alias Jean Marin), Saurat called for support and sacrifices from within and outside France to help save France, 'the mother of all civilized spirits'. ${ }^{46}$ The image of France as a 'mother' who was indispensable to the world was in tune with the rhetoric of de Gaulle at this time, but it was also a logical continuation of Saurat's pre-Armistice ideas. These were present in the four talks Saurat broadcasted on the BBC in December 1939 based on The Spirit of France, a book he was writing at the time. In these radio programmes, he developed ideas which he was to adhere to for the next years: an obvious distrust of Germany and its people, an

\footnotetext{
${ }^{40}$ Julian Jackson, "L’homme du 18 juin : vérité et légende," 27.

${ }^{41}$ AIFRU, DSA 35. 20 and 29 September 1940.

${ }^{42}$ Sudhir Hazareesingh, In the Shadow of the General: Modern France and the Myth of De Gaulle (New York 2012), 7.

${ }^{43}$ Martyn Cornick, "Professor Denis Saurat: From Toulouse to London" (Homage to Denis Saurat and Storm Jameson, Institut français du Royaume-Uni, 2010), http://culturetheque.org.uk/access/@FLUzzqFuyzYFLCHh6R9SQdPUpdvKywMb4YUP2yLqxPlwcprw FNnVs0UDIychN9OtnpzFX.uLjUjEuOjrbfrjrDUcoCRBUK3hc4Wuq.1WLIgYxvtRMHIp78TF.kqbywrq XI1Tw1Sx5Wtv0x2u3ZuNx.pdf..

${ }^{44}$ Examples of his public talks and press articles include: "The reorganisation of Europe" (talk in Norwich reported in Perthshire Constitutional, 15 October, 1940), "Message de Londres aux Français d'Austalie et à nos amis Australiens," Courrier Australien, Journal Hebdomadaire de La France Libre, July 1941; "France waits for another July 14," The Daily Mail, 14 July 1941.

${ }_{45}$ Aurélie Luneau, "Des anonymes dans la guerre des ondes," Le Temps des médias 4, no. 1 (2005): 78 89.

${ }^{46}$ AIFRU, DSA 21. 20 June 1940: entretien Saurat/Morvan/Masson.
} 
attachment to the creation of a Western Union, and the necessity of reforming education. Saurat went on to disseminate similar thoughts in late June 1940, adding Charles de Gaulle as a central figure to his argument. He notably published a piece in the London-based French newspaper France, which drew on an ode to France he had written for the Times Literary Supplement. This piece was an invitation to hope for France's future resurgence, in which he blended the lyric genre with prosaic military references and compared Charlemagne to de Gaulle, the latter of whom he had first introduced to the British audience in a laudatory article published in The Tatler on June $26 .{ }^{47}$

In the words of member of the Resistance and historian Jean-Louis Crémieux Brilhac, Saurat "clearly saw himself as the civilian head of the resistance" ${ }^{\text {" }}$ and briefly had some responsibilities within the nascent France Libre. Following the British attack on the French fleet at Mers-El-Kébir, he met with de Gaulle to draft a Free French official response, arguing for the necessity of a Free French government. On the same day, they established a list of governmental positions and matching personalities whereby de Gaulle was to be president, as well as head of the war and foreign affairs ministries. Emile Muselier was put in charge of the navy and René Cassin, professor at the Faculty of Law in Paris, was assigned to the ministry of national and international law. ${ }^{49}$ As to Saurat, he was listed as minister for education..$^{50}$ Both Muselier and Cassin would come to occupy these positions within Free France whereas Saurat never obtained the role de Gaulle had promised during the meeting. On the same day, and echoing Saurat's interest in civilian matters, he and de Gaulle also discussed the creation of an official document for Free French men and women. This carte d'identité was to distinguish Free French volunteers in Britain from those who British authorities saw as 'enemy aliens'. The meeting also delineated some of the aims of de Gaulle's resistance project which

\footnotetext{
${ }^{47}$ France, 17 July 1940; Denis Saurat, "Victor Hugo - 14 déc. 1852," Times Literary Supplement, 13 July 1940; AIFRU, DSA 21, "Fore-sight," and "The way out of the war," The Tatler, 26 June 1940.

${ }^{48}$ Crémieux-Brilhac, La France LIbre, 96.

${ }^{49}$ René Cassin wrote the statutes of Free France and was afterwards appointed secretary to the resistant Council for Imperial Defense Antoine Prost and Jay Winter, René Cassin and Human Rights: From the Great War to the Universal Declaration (Cambridge 2013).

${ }^{50}$ AIFRU, DSA 21. 5 July 1940.
} 
focused on 'governing the masses'. It was during these meetings that de Gaulle assigned Saurat the role of gathering academics and intellectuals around him. ${ }^{51}$ On 7 July 1940 de Gaulle also told him that his movement needed a 'philosophy'. As a result, Saurat wrote Regeneration, the outline of which he handed over to de Gaulle on $10 \mathrm{July} .{ }^{52}$ On that day, De Gaulle agreed to the publication of the short book and subsequently wrote a letter to Saurat which served as a preface to the text. ${ }^{53}$ In Regeneration, Saurat surveyed the problems of the modern world which he believed was facing a new challenge for 'the masses have become larger, more erratic, and more powerful than they have ever been'. Thus, he explained that civilisation was threatened by tyranny (owing to the need for a leader) on the one hand and uniformity (owing to the homogenisation of individuality) on the other. ${ }^{54}$ The book was for Saurat an opportunity to voice criticism regarding contemporary French society: he disapproved of receding Christian views which had led to a decline of forms of Resistance, and explained the weakness of France by stressing the lack of military preparation (rather than the growth of socialist ideas as the Vichy government and some Gaullist figures would come to formulate). He offered two main solutions to the current international situation which indicate a shift to the right (closer to de Gaulle's ideas), away from his pre-war radical political views. Firstly, a technocratic organization of the world with strong leaders at its head, combined with the possibility to tear down national boundaries and organise world cooperation. Secondly, he believed that the spiritual rehabilitation of the world could only be achieved through a return to religious values and a reshuffling of the education system in order to adapt it to both the elite and the popular classes. ${ }^{55}$ As Saurat's politics focused on religion and leadership, his view became compatible with de Gaulle's tendencies at the time. Importantly for the historians of the French resistance, the notes Saurat took during his meetings with de Gaulle provide an insight into the General's developing strategy to establish himself as a resistance leader who embodied France at a time when we know relatively little about Free French political thought. They reveal

${ }^{51}$ Ibid.

${ }^{52}$ AIFRU DSA 35. 7 July 1940.

${ }_{54}^{53}$ Denis Saurat, Regeneration [with a letter from Charles de Gaulle], (London 1941)

${ }^{54}$ Denis Saurat, Regeneration, 11-12.

${ }^{55}$ Denis Saurat, Regeneration, parts III-IV. 
that de Gaulle's views fitted in with French right-wing politics and borrowed some features from the social psychologist Gustave Le Bon's crowd theories, which were already present in de Gaulle's Fil de l'Epée (1932). ${ }^{56}$ Saurat's notes corroborate de Gaulle's views on a society governed by a strong leader in which democracy or republicanism did not, at that time, come into question. As Julian Jackson has shown de Gaulle believed in 1940-1941 that the French people identified these concepts with the fallen Third Republic..$^{57}$

Saurat's first and most important public gesture, to which no biographies of de Gaulle or histories of Free France have referred, was to introduce de Gaulle and his ideas to Londoners during a public lecture on the civilian population in war-time Britain. ${ }^{58} \mathrm{He}$ had organised the event at the Queen's Hall on 17 July 1940 under the auspices of the IFRU. The hall was full; even civilian observers from Mass Observation attended and noted that 20 per cent of the audience was French and nearly all were middle class, along with a few men in uniform. Whilst it was announced that de Gaulle would chair the event, he arrived late and refused to speak when the audience cried his name. The general exited without a word, leaving Saurat to conclude: 'The general, as is proper in a general, is inflexible... When victory is achieved he will lecture about it.' Civilian observers concluded that it was a 'surprisingly large gathering for such a meeting, people clapped for over two minutes as de Gaulle stood up and left'. ${ }^{59}$ Saurat's talk aimed to boost British morale and its contents followed on a conversation he had had with de Gaulle on 21 June. Among other things, de Gaulle then gave Saurat his permission to act as his public speaker. ${ }^{60}$ Building on his cultural capital and his network, Saurat sought to widen his resistance activities beyond Britain. He did not

\footnotetext{
${ }^{56}$ Kevin Passmore, The Right in France from the Third Republic to Vichy (Oxford 2013).

57 Julian Jackson, Charles de Gaulle (London 2003), 22-23; Jean-Luc Barré, Devenir de Gaulle, 19391943 (Paris 2003).

${ }^{58}$ The only references to this lecture are to be found in Jennifer Birkett, Margaret Storm Jameson: A Life (Oxford 2009), 209; Cornick, "Professor Denis Saurat: From Toulouse to London"; Kelly and Cornick, “'The First Bastion of the Resistance': The Beginnings of the Free French in London, 1940-1."

${ }^{59}$ Mass Observation, Report 288: July 1940, Anglo-French lecture by Professor Saurat: 'Civilians in wartime'. Audience reaction to talk delivered at the Queen's Hall, French institute.

${ }^{60}$ AIFRU, DSA 21, "Silent General," Evening Standard, 18 July 1940; Winifred Holmes (Ministry of Information - Home Intelligence) to Saurat, 23 July 1940.
} 
interact with the metropolitan resistance; rather and in tune with his belief in the power of the Allied Nations he sought to use his acquaintances who were exiled in America. These included Jules Romains to whom he suggested the creation of a 'resistance' French institute in Chicago and New York. Saurat himself had planned to travel to the USA to help with this propagandist mission. Romains declined the directorship of the proposed institute and Saurat never went to North America during the war probably owing to his discord with Free France. ${ }^{61}$

In his unpublished and unfinished memoirs written at the end of the war, Saurat bitterly identified August and September 1940 as pivotal in the change of his position within Free France but also in the history of the London-based French Resistance. These months corresponded to the absence of de Gaulle from London which facilitated the development of the first expressions of anti-Gaullism. It was also a time when Free France became well-established in London and Saurat was thus no longer needed. When Robert Vansittart, the chief diplomatic adviser to HM Government, met with Saurat in mid-September 1940, he commented about the current situation: 'It is beginning to stink' ${ }^{62}$ Besides Saurat's involvement in left-wing circles, his anglophile politics, which de Gaulle had previously overlooked, became increasingly problematic for the General. Saurat was not the only influent anglophile figure in the London French community: other men in his network shared his views that France's victory was to be conducted through an alliance with Britain. This was the case for Roger Cambon, who had warned Saurat against de Gaulle as early as June $26 .{ }^{63}$ Another of Saurat's acquaintances was the charismatic physicist André Labarthe, who had been close to Popular Front politicians and had rallied around de Gaulle in June 1940. After being dismissed from his position as head of weaponry for Free France in early September owing to a strong

${ }^{61}$ AIFRU, DSA 21, Romains to Saurat, 18 October 1940. Romains had pretexted that he was too busy writing instalments of Les Hommes de bonne volonté and that this work would better serve the 'intellectual prestige of France'. Denis Rolland has showed that Romains would become an active voice of French arts and literature in South America from 1942 on. Denis Rolland, L'Amérique latine et la France: acteurs et réseaux d'une relation culturelle (Rennes 2011); Rolland Denis, 'L'exil structure l'émigration (Mexique, Seconde Guerre mondiale)' In: Matériaux pour l'histoire de notre temps, special issue edited by R. Frank 'Pour une histoire de l'Exil français et belge', 67, 2002, 66-77.

${ }^{62}$ AIFRU, DSA 35. 16 September 1940.

${ }^{63}$ AIFRU, DSA 35. 26 June, 1940; Broche, Une histoire des antigaullismes, 73. 
disagreement about his role within the movement, he became the IFRU's scientific director. This position was tailor-made for him by Saurat and was approved by the general secretary of the British Council, Lord Lloyd, who was renowned for his suspicions towards de Gaulle. ${ }^{64}$ The burgeoning mistrust of Gaullists which started to grow within Saurat's entourage was strengthened by Larbarthe and the philosopher Raymond Aron's creation of the political and cultural journal La France Libre in September 1940. The IFRU building sheltered the office of La France Libre which was launched on 15 November 1940 and, in spite of its name, rapidly constituted a counter power to Gaullism. ${ }^{65}$ In the summer and autumn of 1941, Saurat regularly attended Labarthe's dinner parties with Vansittart, the admiral Muselier, renowned for his criticism of de Gaulle's despotism, along with British politicians Duff Cooper, Harold Nicholson and what Saurat called the 'anti-Gaullist cabal' ${ }^{66}$

As Saurat progressively grew closer to anti-Gaullist figures, he became increasingly distant from the Gaullist commissars who he had once supported. This was notably the case with René Cassin who arrived in London with his wife on 28 June, 1940. Upon his arrival, he was driven to the IFRU where Saurat announced that he had rallied to de Gaulle and offered to introduce the two men. ${ }^{67}$ Cassin taught and lived at the IFRU until December $1941^{68}$ and was originally favourable to Saurat's involvement in the National Committee, suggesting to de Gaulle when the latter offered him the position of commissar for justice and education: 'You have a perfect candidate to take care of Public instruction: it's Denis Saurat, the director of the French institute. ${ }^{69}$ Personal, political and professional relationships between Cassin and Saurat deteriorated as Saurat bitterly witnessed the rise of Cassin to a position he had coveted since June 1940. In the

\footnotetext{
${ }^{64}$ AIFRU DSA 35. 17 September 1940. François Broche, "Muselier, Emile (1882-1965)," ed. François Broche and Jean-François Muracciole, Dictionnaire de la France libre (Paris 2010), 842-843.

${ }^{65}$ Saurat wrote several times for La France Libre, partly on issues which he had discussed with de Gaulle ('La tête et les Masses', published in November 1940), partly on issues which were close to his heart and which he had hoped to tackle within the Free French ('La réforme de l'Education Nationale', February 1941) and partly on literary issues ('Les résultats de la psychanalyse', December 1942).

${ }^{66}$ AIFRU DSA 35, notes taken from July until October 1941. Broche, "Muselier, Emile (1882-1965)."

${ }^{67}$ René Cassin, Les hommes partis de rien: le réveil de la France abattue (1940-41) (Paris 1975), 71.

${ }^{68}$ AIFRU, DSA 35. Cassin to Ellul, 17 December 1941.

${ }^{69}$ Cassin, Les hommes partis de rien, 406.
} 
notes of an interview conducted with Saurat in 1951, the interviewer wrote: 'Up until R. Cassin had gained influence upon the general, the relations between S[aurat] and de Gaulle had remained good'. ${ }^{70}$ Intrigues regarding Cassin's free accommodation at the IFRU after he had stopped teaching there worsened the situation. ${ }^{71}$ This, added to Cassin's intervention in IFRU politics (discussed later) rankled with Saurat to an absurd degree and led to several arguments with Cassin in de Gaulle's headquarters, the IFRU or even on Museum Road in South Kensington. Cassin, although less obsessed than Saurat with these petty events, would later describe Saurat as a 'complete bastard'. ${ }^{72}$

As Free France was organising itself without him, Saurat sought to cast the IFRU as an alternative rallying point for the French Resistance. The many plans and lists he wrote down in September 1940 reveal his aspiration of reconciling Gaullists with dissidents. Talking about his resistance ambitions, he had previously explained to his good friend Labarthe: 'we can make anything out of the institute, it's a virgin, unexpected opportunity; we will succeed' ${ }^{73}$ Subsequently, he toyed with the idea of various counter- or alternative movements, whose leaders were to be Labarthe, Gaston Palewski, close advisor to de Gaulle, or Elie Bois, former editor of Le Petit Parisien, a daily newspaper which had strongly opposed the Bordeaux government in June 1940. He also sought the participation of Philippe Barrès, a strident anti-Nazi who joined the Free French in June 1940, and Eve Curie, Pierre and Marie Curie's daughter who had arrived in England in the same month. Saurat himself was to be in charge of the Foreign Office. ${ }^{74}$ Following a so-called 'pact' with Labarthe, he imagined a future cabinet comprising of de Gaulle as head of the army, with Palewski, Labarthe and Saurat

\footnotetext{
${ }^{70}$ AN, 72 AJ 220. Entretien entre Denis Saurat avec Mme Granet, September 1951.

${ }^{71}$ AN, AG 3 (1) 327. Cassin to de Gaulle, 30 April 1942. AN, AG 3 (1) 327. Cassin to de Gaulle, 28 March 1942. In December 1941, Cassin went on an African mission, and Saurat seized the opportunity to let the Cassins' flat on 33 Cromwell Road to General Brunot and his wife, who settled in despite the presence of the Cassins' personal belongings and papers. Upon returning to London, Cassin's wife, “out of consideration for Free France", kept the story quiet. See also Prost and Winter, René Cassin and Human Rights, 151-152.

${ }^{72} \mathrm{AN}, 72$ AJ 220. Note de la visite à M. Cassin par Mlle Gouineau, 14 October 1949. See also the postwar report written by Cassin in AN 382 AP/55, Cassin to Delbos, 3 August 1949.

${ }^{73}$ AIFRU, DSA 35. 20 September 1940.

${ }^{74}$ AIFRU, DSA 35. 21 September 1940.
} 
heading up the Foreign Office, department of propaganda, and Education affairs respectively. ${ }^{75}$

From February until May 1941, Saurat left 'his' institute as de Gaulle sent him on an educational mission to French Equatorial Africa. Under General Governor Felix Eboué, French Equatorial Africa (AEF) had rallied around de Gaulle in August 1940. The AEF was a key place for the external Resistance, and many of de Gaulle's advisors went on missions in this region. ${ }^{76}$ Saurat was no exception, although his case appears more complex. In the book he wrote following his trip, Saurat reported that de Gaulle had introduced the job as an enquiry into the spiritual and educational needs of the masses'. ${ }^{77}$ This episode once more suggests that de Gaulle viewed Saurat very instrumentally. On the one hand, Saurat had a thorough knowledge of the aims and challenges of education, which had appealed to de Gaulle since their first meeting. On the other hand, Saurat's increasingly marginalised position within Free France suggests that this 'educational mission' was one way for de Gaulle to side-line him further. ${ }^{78}$ Saurat nonetheless accepted the mission, perhaps because he saw it as a way to regain de Gaulle's benevolence and ultimately obtain a position within Free France. During his trip, Saurat went on Radio-Brazzaville to discuss 'the wonderful resistance of the British Empire' and the British people's attitude towards bombings. ${ }^{79}$ Saurat's laudatory broadcasts in favour of Britain were not well received by the Free French who hindered his media interventions upon his return from Africa. Saurat had proposed a series of four broadcasts on the BBC discussing the post-war order but this was met by a persistent refusal from Free French officials. ${ }^{80}$

From the spring of 1941, remarks on Gaulle's entourage, once confined to personal notes and private conversations, began to pepper Saurat's conversations with de Gaulle. These pointed towards the difficulties of structuring and running Free France in an

\footnotetext{
${ }^{75}$ AIFRU, DSA 35. 25 September 1940.

${ }^{76}$ Eric Thomas Jennings, La France Libre fut africaine (Paris 2014).

${ }^{77}$ Denis Saurat, Watch over Africa, 9.

${ }^{78}$ AIFRU, DSA 35. May 1941.

79 “Le professeur Saurat à Radio-Brazzaville,” France, 3 April, 1941.

${ }^{80}$ AIFRU, DSA 35. May 1941.
} 
efficient fashion as well as towards the important Jewish presence within Free France that historians have acknowledged and that Saurat saw suspiciously. ${ }^{81}$ Initially Saurat criticised members of Free France, whom he portrayed in his unique, laconic style: 'mayhem, havoc, factions, parties, Jews' ${ }^{12}$ It was but a short step for Saurat to comment upon de Gaulle's strong personality and the lack of democracy within Free France. He was one of the earliest amongst the men who had rallied around de Gaulle to take this line: in October 1941, he set down on paper his concerns about the 'military one man show' de Gaulle was putting up by refusing to be surrounded by independent thinkers. ${ }^{83}$ Saurat was not alone in his anxiety about de Gaulle's authoritarian attitude. Some French men had preferred working solely with British authorities; ${ }^{84}$ other French political figures were worried about de Gaulle's dubious Republicanism. The socialist Félix Gouin, the leader of the Libération-Sud resistance movement Emmanuel Astiers de la Vigerie, or Henri de Kerillis would voice similar concerns from 1943 on. ${ }^{85}$ As to Saurat's preoccupation with rebuilding democracy in France, other figures, notably amongst the French and British left, would come to share it during the war. ${ }^{86}$ However, up until 1942, Saurat's thoughts on de Gaulle remained mostly private and, like many men on the left such as Léon Blum, his belief that resistance activities could only develop from within the Free French circle prevailed. ${ }^{87} \mathrm{~A}$ shift occurred that year perhaps because he now understood clearly that de Gaulle would never appoint him to a Free French official position and also because de Gaulle had made clear that he would

\footnotetext{
${ }^{81}$ Nathan Bracher, "Up in Arms: Jewish Resistance against Nazi Germany in France," in Jewish Resistance Against the Nazis, ed. Patrick Henry (Washington 2014), 80; Jewish Free French amount for around $4.5 \%$ of all Free French which is four times more than the proportion of Jews in France at the time. Jean-François Muracciole, Histoire de la résistance en France (Paris 1993), 168.

${ }^{82}$ AIFRU, DSA 35. 24 October 1941.

${ }^{83}$ AIFRU, DSA 35. 9 October 1941.

${ }^{84}$ Robert Gildea, Fighters in the Shadows (Harvard 2015), 106-107.

${ }^{85}$ Félix Gouin's report, quoted in Pierre Bloch, De Gaulle, ou Le temps des méprises, 72-81; 115; Henri de Kerillis, De Gaulle dictateur. Une grande mystification de l'histoire (Montréal 1945), 14-15.

${ }^{86}$ Emile Delavenay, Témoignage d'un village savoyard au village mondial (1905-1991) (Aix-enProvence 1992) 266. See the interview he conducted with Jean-Jacques Mayoux, professor of literature at Nancy University, who had fled to London. Emmanuelle Loyer, Paris à New York, 188-192. Labarthe questioned the lack of democratic representation within the resistance and was close to Henri Giraud and the Jaures group; Robert Belot, La résistance sans de Gaulle, 512-517. Labarthe's review took a stance in favour of co-operation with the USA and the United Nations from November 1942.

${ }^{87}$ Christian Bidégaray, "Antigaullismes de Gauche," ed. Claire Andrieu, Philippe Braud, and Guillaume Piketty, Dictionnaire de Gaulle (Paris 2006), 41.
} 
not relinquish France's interests to the US and Britain. ${ }^{88}$ This stance clashed with Saurat's anglophilia and internationalism and the director of the IFRU publicly expressed his concerns over Free French international politics in public lectures and British newspaper columns. The first of these articles was published in May 1942 in The Times and challenged the situation of the French Empire, access to which Saurat believed had to be granted to America and Britain in order to facilitate France's victory. ${ }^{89}$ In November of the same year, Saurat published a second article in The Times in which he deplored the absence of 'any democratic principles' in the CNF (Comité National Français, the successor of Free France). Once again, Saurat favoured a global solution as he believed that international intervention, along with the participation of members of the French Parliament who had rebelled against Vichy, as well as exiled intellectuals, diplomats or administrators could restore democracy.. He explained that this would give 'the United Nations some idea of what enlightened opinion in France may be.... So far we have only generals and admirals speaking for France. Should they not be the servants of the state and not its masters?'90

In retaliation, Saurat was kept out of Free French official events and de Gaulle forbade civilian and military Free French attendance at the IFRU unless authorised by the CNF. ${ }^{91}$ Saurat's exclusion from circles that he had coveted so much only served to reinforce his antagonism to de Gaulle. In spite of de Gaulle's changing attitude towards the role of political parties within the Resistance, his increasingly positive outlook on the Republic and the rising number of former deputés among Free French circles from 1943 onwards, Saurat's anti-Gaullism continued to grow. He nonetheless somewhat adapted his criticism to de Gaulle's new political view, leaving aside condemnation of

\footnotetext{
${ }^{88}$ De Gaulle's November 1941 Oxford speech in which he reasserted France's international position against the recently signed Atlantic Charter is seen by many historians as characteristic of the developing Gaullist doctrine which has partly focused on France's independence vis à vis Britain and America. JeanFrançois Muracciole, 'Les discours de guerre du général de Gaulle', in De Gaulle chef de guerre, 144154. Daniel J. Mahoney, De Gaulle: Statesmanship, Grandeur, and Modern Democracy (Westport, Conn.; London1996). See also the conference organised around the 1941 Oxford speech, "De Gaulle before Oxford." Maison française d'Oxford, 2011.

${ }^{89}$ Denis Saurat, 'Letter to the editor', The Times, 6 May 1942.

${ }^{90}$ Denis Saurat, "letter to the editor," The Times, 18 November 1942.

${ }^{91}$ AIFRU, DSA 35. May 1942
} 
de Gaulle's total power which he had favour in 1942. Saurat had some involvement in a January 1943 anti-Gaullist campaign launched by The Observer which stressed the importance of civilian, rather than military representation..$^{92}$ Saurat was prompt in supporting the paper and engaged in a broad discussion on the CNF's political and international strategy. In a published reply, he argued for 'full co-operation with the Anglo-Saxon democracies and the Friendly powers in Europe [as] a military representation of France at the Peace Conference is unthinkable'. Whereas de Gaulle fought to maintain his independence from Britain and the USA as both governments had post-war plans for France that greatly departed from his, Saurat's promoted inter-allied cooperation as France's best bet to win and end the war. Saurat had first articulated concerns with democracy in relation to the figure of de Gaulle but as de Gaulle's views on this point evolved, thus somewhat discrediting Saurat's initial bone of contention, the IFRU director also integrated concerns over Gaulle's strategic choices in the war.

Saurat was part of a heterogeneous London-based anti-Gaullist constellation, and he quickly became one of de Gaulle's bêtes noires. This not only owed to his international approach to politics and his anglophilia but also to his lack of cooperation in supporting Gaullist propagandist ambitions. Whilst Saurat was voicing criticism regarding the political trajectory of Free France and the CNF under de Gaulle, another fight was occurring behind the IFRU's doors that would further fuel his anti-Gaullist sentiments. As early as 7 July 1940, de Gaulle had offered to Saurat to 'take care of' the IFRU, ${ }^{93}$ a proposal which remained unanswered. In the eyes of Général Catroux, the commanderin-chief of the Free French Forces and general delegate of Free France in the Middle East, the IFRU along with the French law School in Cairo were France's two most prestigious cultural institutions. ${ }^{94}$ At a time when French cultural institutions abroad became key pawns in the fight for the liberation of France, not least because they contributed to the political legitimation of the external resistance, the Free French had clear ambitions for the institute in London. For René Cassin the issue of continuity was at the heart of the politics of the IFRU and he regarded Free France as the 'keeper of

\footnotetext{
92 "Amity with France," The Observer, 3 January 1943.

${ }^{93}$ AIFRU, DSA 35. 22 August 1940.

${ }^{94}$ CADN, 378 PO C2 253. Catroux to Cassin, 9 January 1941.
} 
French institutions and traditional spirit; we consider it as our duty to see to the continuation of French culture and especially to support the London French institute in this area. ${ }^{95}$ However, what exactly was the 'traditional spirit' of France in the context of occupation and Vichy France and at a time when some members of the external Resistance also contested the cultural identity born out of the Third Republic? In many respects, the CNF and its successor the CFLN (Comité Français de Libération Nationale) sought to pursue the Popular Front's aim of intensifying the diffusion of a positive image of France abroad but also sought to use culture as a way to assert their legitimacy against Vichy. ${ }^{96}$ This was what Paul Vaucher, a professor of modern French history at the University of London and head of the CNF education department, had in mind when he wrote in 1943 that the IFRU was to be a 'foyer national' and a tool to help France regain its prestige. ${ }^{97}$ Saurat shared both these aims but refused to countenance the assimilation of the IFRU into a Free French institution; rather he was keen to further the relations between the institute and international cultural associations such as the PEN Club and the Cultural Association of Western Countries which the Free French saw as irreconcilable with a purely Free French policy. ${ }^{98}$

However, the IFRU chairman Lord Bessborough (who was also the head of the British government programme 'French Welfare') increasingly came to support Free French ambitions regarding the institute. Bessborough had wanted to make up for the absence of French authorities from the IFRU administration ever since the Paris-Lille academic commission, which served as the pedagogic foundation of the IFRU, had become legally invalid following the Armistice. In combination with Cassin's legal skills, Bessborough offered the CNF an opening into the management of the institute through

\footnotetext{
95 TNA, BW 31/23. Cassin to Bessborough, 3 October 1943.

${ }^{96}$ Pascal Ory, La belle illusion: culture et politique sous le signe du front populaire, 1935-1938 (Paris 1994).

${ }^{97}$ TNA, FO 371/ 28472 and AN, 3 AG 1 285. Note du comité des FGB, 27 March 1943.

98 The aim of this Union was to boost European national and regional cultures and, strengthen spiritual cooperation. Saurat presided over the union; the playwright Charles Morgan and Jacques Métadier represented Britain and France respectively. Officials from the USA and other European nations including the Basque country and Catalonia were involved. On the initiative of the Cultural Association of Western Countries see "Union culturelle occidentale," Free Europe, 29 February 1943. On Free French views on internationalism at the IFRU see AN, 382 AP/55 Rapport sur l'IFRU et ses relations avec la France Combattante.
} 
the so-called 'Cassin-Bessborough agreement', signed in October 1942. This agreement enabled the creation of a new pedagogic committee composed mostly of academics, three of whom were to be nominated by the CNF (Commandant Schaeffer, Professors Cathala and Voisine). The duties of this education committee included assessing the teaching at the IFRU and reviewing the programme of lectures. In addition the head of the CNF foreign and colonial ministry, René Pleven, and Paul Vaucher were elected members of the IFRU council. Their role was to inform the CNF of the policies being pursued by the institute as well as put before the IFRU council the views of the CNF. This allowed them to make extensive recommendations regarding the IFRU programme which they judged did not sufficiently showcase French topics. They also prevented the organisation of specific events such as a lecture to be delivered by the former Free French Muselier. ${ }^{99}$ The committee failed however to end Saurat's weekly lectures on the situation of France which de Gaulle regarded as politically toxic. ${ }^{100}$ As the CNF united with Henri Giraud's Commandement en Chef Français Civil et Militaire to form the CFLN in June 1943, the IFRU executive council and the British Foreign Office announced that the Cassin-Bessborough agreement, which specifically linked the IFRU with the CNF, was redundant, much to Saurat's delight. ${ }^{101}$ Leaders of the CFLN, however, were keen to keep the upper hand in the IFRU and they sought to bypass the obsolescence of the Cassin-Bessborough agreement by turning to the University of Algiers. This institution had become the first Free French University, inheriting the power of French metropolitan universities, including in their relations with academic institutions abroad such as the IFRU. ${ }^{102}$ By that point, the Free French were not only keen to set up a cultural diplomacy of their own, but also to engage in designing an academic diplomacy so as to gain legitimacy amongst intellectuals and academics. However, Free French ambitions were once again frustrated as Saurat, the British

\footnotetext{
${ }^{99} \mathrm{AN}$, 560/AP 26. Compte rendu de la séance de la commission d'enseignement de l'IFRU, 27 February 1943.

${ }^{100}$ TNA, BW 31/23. Rapport de la première réunion du Comité d'Education, 11 December 1942. CADN, 378 PO C2 253. Comité National Français (London) to de Gaulle, 12 July 1943.

${ }^{101}$ CADN, 378 PO C2 253. Vaucher to Viénot, n.d.

102 CADN, 378 PO C2 253. Journal Officiel, ordonnance du 10 novembre 1943; Chantal Morelle and Pierre Jakob, Henri Laugier: un esprit sans frontières (Bruxelles 1997); Jean-François Muracciole, Les Enfants de La Défaite: La Résistance, L'éducation et La Culture (Paris 1998), 30-33.
} 
Council and the IFRU board of trustees firmly rejected the proposal that the University of Algiers should gain any power over the institute. All three parties including Lord Bessborough were hoping that the end of the war would come soon and that the IFRU would then be able to resume relations with the Universities of Lille and Paris. Besides Bessborough feared that an agreement with Algiers would trigger Saurat's anger which might potentially encourage him to lead a harmful press campaign against British authorities. Finally (and this was Saurat's opinion rather than that of British authorities), some trustees expressed concern that the transfer of academic power to the University of Algiers might put the University of Lille in the shade after the end of the war. ${ }^{103}$

In the summer of 1944, three bombs fell close to the IFRU: Saurat was injured and stayed away from London for several months. This was the perfect opportunity for the French provisional government (GPRF), which had been constituted in Algiers in June 1944 and was presided over by de Gaulle, to settle the IFRU affair and take over its managerial control. ${ }^{104}$ As the allies progressively liberated the north of France, the IFRU resumed pre-war relations with the Lille and Paris academic commission. The latter was prompt to agree that Saurat had to be replaced owing to his anti-Gaullist stance. The commission sent Lille academic Emile Audra, who had directed the IFRU after the end of the First World War, to conduct an initial two-month mission in London which was to have tremendous consequences for the future of the IFRU. He reported on the paradoxical legal and financial position of the IFRU: although it was a British association with an executive council mostly composed of British men, the institute had been almost entirely funded by the French government before the war. Audra concluded that the administrative - and not solely pedagogical - management of the IFRU should be granted to France via the universities of Paris and Lille to enable an inspection of the use of the French government's money. ${ }^{105} \mathrm{He}$ thus delineated the first lines of the argument to transform the IFRU into a fully French association which would allow the

103 CADN, 378 PO C2 253. Viénot to Massigli, 10 February 1944.

${ }^{104}$ AN, AJ 16 6948. G. Bidault (MAE) to Ministère de l'Education Nationale, 13 October 1944.

105 AN, F 17 25396. E. Audra Memorandum sur l'Institut Français, 2 February 1945; AN AJ 166948. Audra au recteur de Paris: rapport présenté à M. le Recteur, président de la commission interuniversitaire Paris-Lille par M. Audra, 1 December 1944. 
Paris-Lille commission to take over the administrative management, and thus see to Saurat's dismissal. ${ }^{106}$

Although Saurat was kept out of these negotiations, he was fully aware that the Lille and Paris commission desired to have him removed and conducted an intensive campaign in the British national press regarding what he thought would be an unjust dismissal. ${ }^{107}$ Consequently some council members, 100 IFRU members along with influential sympathisers including T. S. Eliot, E. M. Forster, George Orwell and Rebecca West signed a petition against Saurat's removal. ${ }^{108}$ This appeal had no impact, but it showed the extent to which Saurat had gained support within the British intellectual world. In early March 1945, the IFRU council agreed to the voluntary dissolution of the IFRU as a British association in order to enable the Paris-Lille commission to take over as sole managing body. On 26 March 1945, the rector of Lille announced to Saurat that his mission would be terminated once the administrative council passed over its power to the next administration. ${ }^{109}$ For Storm Jameson, this was evidence of de Gaulle's dictatorial power; she wrote to Ould that she 'hoped de Gaulle would soon be done with: it seems a pity to spend years and destroy Europe to put down one dictator, and set up another in Paris'. ${ }^{110}$ This period witnessed the end of Saurat's 24-year long directorship and triggered the setting up of a new executive structure for the IFRU which was to be largely influenced by longer-term strategies of the growth of state power in Western Europe, France's post-war cultural diplomacy and the FrancoBritish cultural convention signed in 1948. In spite of his eviction at the head of the

\footnotetext{
${ }^{106}$ AN, AJ 16 6948. Vaucher to French Embassy in the UK, n.d. Encouraged by Paul Vaucher Lord Bessborough, the president of the IFRU council, started lobbying along those lines and the board of trustees came to agree with the proposal.

${ }^{107}$ NA, BW 31/33. Lane to E. Ellul, including a memorandum on the constitution of the Institut Français and its relations with the French authorities, 14 November, 1944. "Saurat will not resign: 'political demand'," The Sunday Express, 31 December 1944; "French Institute in London - director asked to resign," The Times, 1 January, 1945; "Prof. Denis Saurat," The Daily Telegraph and Morning Post, 3 January, 1945. In these articles, Saurat explained that the French government had no right to ask him to resign because the IFRU is a British association. He further declared: 'I am afraid this is a question of political interference, and politics should not interfere in University matters'.

${ }^{108}$ CADN, 378 PO C2 253. W.C. Walgate to Bessborough, 1 March 1945.

${ }^{109}$ AIFRU. Report of the meeting of the general council, 8 March 1945. AN, AJ 16 6948. Recteur of the University of Lille to Saurat, 26 April 1945.

${ }^{110}$ Letter from Margaret Storm Jameson to Ould, 10 March 1945 (PEN archive (London, uncat.), HRC) quoted in Birkett, Margaret Storm Jameson, 260.
} 
IFRU, Saurat retained the Chair of French at King's College until 1950, during which time he stood as a potential rival to the institute. ${ }^{111}$

By focusing on de Gaulle and his entourage early histories of Free France have tended to maintain the myth that, in the early $1940 \mathrm{~s}$, as Radical député Pierre Mendès-France reportedly said: 'In London, one cannot but be a Gaullist'. ${ }^{112}$ Looking at Denis Saurat's trajectory during the war offers a more nuanced approach to the relationships between the London French community, de Gaulle and the Free French. It firstly shows that antiGaullism was a significant political force in London, even though much of the literature about this topic has focused on French exiles in the United States or the post-war attitudes of disillusioned resistance fighters. It also allows historians to consider alternative resistance circles in London, some of which progressively came to embody one strand of anti-Gaullism. Saurat was but one intellectual who challenged de Gaulle's ideas from outside France. ${ }^{113} \mathrm{He}$ was, however, one of the rare figures who could actually hinder de Gaulle's cultural and educational project because he was at the head of one of the oldest French cultural institutes located in the Free French capital city. In reaction to de Gaulle's diminishing interest in promoting him to a Free French executive role, Saurat became a fervent and public anti-Gaullist who was critical of the person of de Gaulle first and Gaullism second. This ultimately led to his dismissal from the IFRU in the spring of 1945. Saurat's trajectory during the Second World War is thus comparable to that of a few other men who put themselves at the service of de Gaulle, only to be excluded from Free French circles and reacted by developing strong antiGaullist feelings; another was the conservative député Henri de Kérillis who spent most

\footnotetext{
${ }^{111}$ AN, F 17 25396. Saurat to Directeur de l'Enseignement Supérieur, 20 October 1949. French authorities reported in 1947 that he was attempting to rally around him IFRU lecturers and British Francophiles, making King's College a challenger to the IFRU. Saurat caused a diplomatic incident by inviting Jules Supervielle to speak at King's College London without informing the French Embassy. CADN, 378 C 2 545. Ambassador to Teitenger, 29 September, 1947 and Ambassador to MAE, 3 October 1947.

112 This is what Mendès-France ascertained to the Aisne socialist député Pierre Bloch on his first day in London. Pierre-Bloch, Londres: capitale de La France Libre (Paris 1986), 19.

${ }^{113}$ See for example Loyer, Paris à New York.
} 
of the war in the United States. ${ }^{114}$ Besides, contrary to many French intellectuals for whom London was only a stage in their exile to America, Saurat stayed in Britain. From there, the tensions around him and de Gaulle, Cassin and the CNF were exacerbated owing not solely to a clash of personality but mostly because of diverging political views and international strategies along with an essential disagreement over the independence of the French cultural institute. Thus Saurat's public anti-Gaullism and progressive exclusion from Free French circles and, ultimately, from French cultural diplomacy are best understood through the history of the political ideas and cultural ambitions of Free France. By focusing on the war-time trajectory of Denis Saurat, this article points towards individuals who, although they served Free France for a brief moment, remained at its margins. It renders more complex the very useful dichotomy that many historians adhere to, between the 'résistance organisation' of political institutions, clandestine resisters and official members of Free France and its Free French forces and the 'résistance mouvement' which encompasses indirect support provided to the 'Resistance-organisation'. ${ }^{115}$ This essay also stresses the continued need for a large-scale study of the non-Gaullist external Resistance in order to take into consideration those French resisters who vacillated between their belief in the Resistance and political, ideological and personal commitments. Finally it also suggests that external resisters were important 'agents of internationalism' who sustained networks with the Allied nations and Francophiles throughout the world, beyond the Free French capitals of London, New York and Brazzaville. ${ }^{116}$ The history of these resisters who expressed concerns for post-war France from every corner of the globe should allow scholars to reflect on how transnational communities - and not solely the

\footnotetext{
114 Jean-Yves Boulic and Annik Lavaure, Henri de Kerillis: L'absolu Patriote (Rennes 1997).

115 Jean-François Muracciole, Les Français libres: l'autre Résistance (Paris 2009). François Marcot, 'Les paysans et la Résistance: problèmes d'une approche sociologique' in Jacqueline Sainclivier and Christian Bougeard, (eds), La Résistance et les Français : enjeux stratégiques et environnement social, (Rennes 1995), 255.

${ }^{116}$ See for example the case of Pierre Denis and Free French economic and financial policy Philippe Oulmont, Pierre Denis, Free Frenchman and Citizen of the World (Paris: Nouveau Monde, 2013). On the concept of 'agents of internatinoalism' see Jessica Reinisch, "Introduction: Agents of Internationalism," Contemporary European History 25, no. 2 (May 2016): 195-205. Finally on the global approach to the history of Free France, see Sylvain Cornil-Frerrot and Philippe Oulmont, Les Français Libres et le monde: Actes du colloque international au Musée de l'Armée, 22-23 novembre 2013 (Paris 2015).
} 


\section{elite of Western liberal internationalism - have shaped the French nation after the Liberation.}

